\title{
Architecture as Meaningful Language: Space, Place and Narrativity
}

\author{
Nikolaos-Ion Terzoglou \\ School of Architecture, National Technical University of Athens, Greece
}

Copyright $\bigcirc 2018$ by authors, all rights reserved. Authors agree that this article remains permanently open access under the terms of the Creative Commons Attribution License 4.0 International License

\begin{abstract}
A semiotics of architecture should focus on the process of the production of meaning through the articulation and organisation of space (and time). This articulation has, at least, a mental side (conception) and a material side (realisation). However, it would be misleading to try to reduce this double articulation into a formal logic alone (Pierce). Proxemics has convincingly demonstrated that spatial forms are part of social life and that their meaning depends on (and refer to) cultural values. We should study and think of the semiotics of space in the broader context of a semiotics of culture, insofar as its system of signs aims at the production of cultural meaning that is part of a code of social hierarchies and distinctions. In this paper, I propose a preliminary intersection between semiotics, literary theory and modal narratology. To decipher the social values that are inherent in spatial forms we need not only a general theory of their interpretation but also a theory of their manner of telling, their narrative structure, their plot, and how this plot is anchored and activated into specific and determinate social chronotopes. A possible strategy that would allow for the above intersection to take place could be a broad conception of the notion of 'text' that includes 'space' as a narrative process and as a discourse that follows a specific 'narrative grammar'. Therefore, architectural semiotics should lay emphasis on the process of the conception, design and production of spatial meaning as if this process was the writing of a social text, a codification of a narrative in space. In this paper, I will focus on a fragment of this project, examining some of the semiotic correlations and conceptual conjunctions between literature and architecture.
\end{abstract}

Keywords Space, Place, Life-world, Prefiguration, Configuration, Refiguration

\section{Introduction: Brief Overview and Evaluation of the History and the Problems of the Relationships between Architecture and Semiotics}

\subsection{Semiotics, Architecture and Space}

Semiotics is the study of the generation of meaning through the systems of signs. Today, we can claim that the production of meaning is a process. Meaning is constructed as a shared system of signification. For Saussure, language is such a complete system of signs and their formal relations, which allows for a conventional articulation between signifiers and signifieds. It seems that, for Saussure, semiology was seen as a science of signs. During the 1960s and 1970s, when Saussurean linguistic structuralism was applied and expanded to other fields (e.g. anthropology, history of ideas, psychoanalysis), postmodern architectural theory attempted to incorporate the powerful and emergent field of semiotics (or semiology) into an examination of spatial meaning [1], trying to overcome functionalism. For Charles Jencks [2], a protagonist of postmodern architectural theory, which developed as a critique of modernism's 'negation of meaning, "any form in the environment is...capable of being motivated...the minute a new form is invented, it will acquire, inevitably, a meaning". Jencks [3] believes that "we are...condemned to meaning" due to cultural preconceptions that are dominant. Geoffrey Broadbent [4] said something similar: "all buildings symbolize...they inevitably carry meaning". Jencks' own interpretation of semiotics resides in an application of Ogden and Richards's 'semiological triangle';[5] that is, a relation between percept (referent), concept (content) and word (symbol). Jencks believes that knowledge and language determine what we see and perceive in the world. Meaning is produced by the projection of conceptual schemata on the observable facts and is intimately connected with expectancy. Architectural meaning oscillates between the architect's intentions and the people's reactions [6]. However, architecture as a meaningful construct has a triple articulation and not a double one, as the Saussurian sign - form, function and technic [7].

Gillo Dorfles [8] agreed with Jencks, he believed that architecture is a sign system, an "institutionalized ensemble of signs" that are related to the inhabitant's behaviour. However, there is a difference between 
language and architecture, which are both considered as sign-systems - language is composed of single, discrete units, whereas architecture must consider relationships to create meaning, which are an ensemble of many signs that are articulated in multiple planes and degrees of complexity [9]. Dorfles [10] writes: "an architectural code...cannot be reduced to discrete units, identifiable with those of the common spoken language". Meaning in architecture is connected with wholistic, complex spatiotemporal dimensions of experience [11]. Geoffrey Broadbent [12] revealed another difference between architecture as a design process and language, which is extremely crucial. In language, we move from the material signifier-from the word - to the signified - to the meaning, the concept of a word. In architectural design we do the opposite! We move from an abstract concept-a signified pre-existing meaning that we project on the space-to-be-constructed - to the material building, which then becomes a signifier - an embodiment of our previous abstract thinking. Philippe Hamon [13] writes something quite similar: "In architecture, it is fiction (the blueprint) that precedes the real (the constructed building)". According to Broadbent [14], it is the social contract of each historical period that will determine which values and ideas will be important as possible signifieds of architecture, which then becomes a sign of "some pervading philosophy". Christian Norberg-Schulz [15] seems to agree, when he writes that "as a work of art, architecture concretizes 'values'. It gives visual expression to ideas which mean something to man". Norberg-Schulz [16] is against functionalist and homogeneous space; instead he aims towards a symbol-milieu, an environment of meaningful forms as a system of meaningful places.

Umberto Eco's idea of semiotics as the study of all aspects of culture as communicative processes did not neglect to incorporate architecture as an important part of that study. In his famous analysis of the column, which was developed in an article published in 1972, Eco [17] claims that architectural signs are a "system of...objects and...spaces that communicate possible functions". However, we should not read this statement as a functionalist credo. Eco [18] quickly elaborates: "in architecture the communicative aspect predominates over the functional aspect, and precedes it". The signified functions of architecture are not uses but types - classes of possible functions: "they are cultural units, before being practical acts". Eco [19], in this article and also in his major work La Structure Absente, clarifies that there are two basic types of 'function' in architecture: the primary, utilitarian function is related to use and acts like a denotation; while the secondary function is related to symbolical values, cultural conventions and ideology and reminds us of a connotation. Eco [20] believes that "for many architectural 'objects' communication of the secondary functions is more important (socially and ideologically) than communication of the primary functions". However, as soon as he starts wondering on the nature of the significative units in architecture, Eco [21] seems to regress to a linguistic formalism of separate morphemes and 'choremes', which Dorfles had already transcended. Form seems to be important in the articulation of the meaning of an object as long as the primary, denotative function is considered. As soon as one moves to the secondary, connotative function, space becomes important. For example, Eco [22] writes on the column: "the greater part of these connotations (secondary functions) is associated with its spatial and temporal context". Architecture's specificity is the fact that it persists in time, creating spatiotemporal complexes (con-texts) with synchro-diachronic qualities [23] that cannot be reduced to a structuralist, synchronic analysis, like language. To use Mario Gandelsonas's vocabulary [24] against his own argument, I claim that architecture cannot be reduced to its syntactic dimension-its semantic, cultural dimension (i.e. its 'external meaning') is stronger than the internal attributes of form. This is what Eco [25] calls 'exterior codes': namely, anthropological systems of cultural unities that correspond to human demands and values, to 'existential desiderata' that have a proxemic dimension. He writes [26]: "The architectural sign becomes the signifier $\mathrm{X}$ denoting a spatial signified - which is a function $\mathrm{Y}$ that in its turn becomes a signifier connoting a proxemic signified (a social value K)". The rhetorical and social meaning of space cannot be reduced to an aspect of its syntactic dimension [27]. Spatial meaning is produced through successive acts and decisions that aim at signification of value. The intention of the project unfolds a narrative sequence. According to Albert Levy [28], tropes of multiple 'registers of space' form paradigmatic associations, isotopes of complex spatial meaning that articulate ideas based on selection and combination. Crucial in this process is what he calls 'meta-operators', such as the 'parti' and the concept, which ground the generative grammar of the conception on the memory of architectural history and on other disciplines, outside the architectural field.

Today we are faced with an epistemological problem - When does the meaning of space arise? Does it reside solely in the built object itself? Does it arise during the design process of its conception? Is it articulated during the appropriation of its built outcome by the people who live within it? And, can we claim that space itself is a nexus of relations and is not singular buildings or autonomous objects [29], which produce meaningful events?

\subsection{Architecture: Language (Langue) or Speech (Parole)?}

This paper will start by arguing that architecture is a more general, non-linguistic, synchro-diachronic, wholistic 
sign system, whose secondary, connotative function is dominant. Since Roland Barthes's work in the 1950s, semiotics has investigated cultural phenomena other than natural languages, focusing on the connotative mechanisms that are articulated around every day 'myths', power and ideology. According to Barthes, human space is a signifying space par excellence and the city can be considered as a form of writing. For example, he argues [30]: "The city is writing; the man who moves about in the city, i.e., the city's user...are a sort of reader". The architecture of the city communicates ideology, values, power relations and cultural feelings and meanings through plural strategies of writing on the body of the city. Barthes [31] continues: "The city is a discourse... the city speaks to its inhabitants...the city is a poem". Therefore, a semiotics of architecture should focus on the processes of the production of meaning, values, feelings, ideologies and power through the articulation and organisation of space (and time) in a symbolic capital. This articulation has, at least, a mental side (conception) and a material side (realisation).

In contrast, according to Algirdas Julien Greimas [32], space is a language: "The language of space appears...as a language through which a society signifies itself". There are two dimensions to what Greimas [33] calls a 'topological semiotics' (sémiotique topologique): the spatial signifier, the world of common sense, and the cultural signified, the imaginary referent. However, it would be misleading to try to reduce this double articulation of architecture into a formal logic alone, into semiotics as a general science of signs carrying meaning (C.S. Pierce) or into an algebraic formula of typical relations (Greimas), as if architecture was only a natural language like any other. For example, Greimas [34] argues in favour of 'topological objects in general', 'classes', 'invariant models', grammars and a syntax of spatial figures. Objects are reduced to 'properties' and subjects to 'roles', as syntactic instances of an abstract, timeless, 'scientific' and 'objective' model.

Barthes [35] reminds us that "signification is experienced in complete opposition to objective data". The problem of using semiotic models with a mathematical, algebraic and formal structure and objective logic to explain architectural space is their abstract and reductive nature. Lived space (place) is not abstract. Even Greimas [36] admits that living the city transcends the linguistic model: "the city could be considered as a text...its user could be defined as the interpreter of urban space...the city-text is made of people and things, of their relations and interactions". Architectural space is concrete, made up of things, the relationships between them and the void, their sensations [37] and the feelings that they produce, which all create meanings. According to Broadbent [38], the specificity of architecture as a sign system transcends language: "architecture seems to me so much richer in the way it 'carries' meanings to all the senses". The city is an open work. To decode its multiple meanings, the user must provide his or her own interpretation. According to Alain Rénier [39], the textual co-operation of the recipient is crucial in evaluating architectural space as a social and institutional field, where schemes of actions organise narratives. Therefore, if we adopt an abstract model and then try to 'apply' it to a real spatial situation, then we risk missing the point altogether. This epistemological obstacle was the main problem of structuralism. The structuralist models that tried to explain architecture were abstract, timeless and formal. If we adopt Pierre Boudon's terminology, then I am mostly referring here to what he calls 'sémiotique'. These models are inspired by Pierce and Chomsky, and they produce types of grammars that analyse forms and figures of space per se to arrive at a 'morpho-syntaxe' [40]. Therefore, we should not look for the 'incarnation' of a structure in reality. In that sense, reality becomes just a 'moment' of the structure - a kind of symptom. However, reality has an inner articulation and dynamic of its own, and architecture has a decisive role to play in that articulation. Architectural meaning is born out of a complex historical correlation of concrete spatial relations, experiences and conditions, and it is not a formal instance of an abstract structure. Consequently, in this study I adopt Boudon's [41] concept of 'sémiologie', claiming that urban forms refer to something outside themselves, namely: to lived experiences and discourses.

Proxemics has convincingly demonstrated that spatial forms are a part of social life and that their meaning depends on (and refer to) cultural values. Consequently, a semiotics of architecture and the city seems to lie closer to the humanities because the way that humans interpret spatial meaning is absolutely crucial for its relation to social values. Therefore, the quest for spatial meaning should place more focus on the response, reception and use of space by its inhabitants. Following the Saussurian semiotic model, and its distinction between langue and parole, we could claim that if built space is a static language, then its reading, reconstruction and use by the people is the discourse, the speech, the oration [42] that gives it meaning and which attaches values to it. However, architectural design as a mental process bears a similarity to the appropriation of space by its users, insofar as it is not an abstract, formal processing of a given code or a management of already established shape grammars. It is rather a speech, an utterance (enoncé) [43] of the individual architect, while using and appropriating a given, codified system. For example, if we claim that 'modernism' became a codified system of rules and grammars for the articulation of space, namely an 'architectural language', then the way that Le Corbusier 'speaks' is different from the way that Walter Gropius or Alvar Aalto utter their phrases. This remark concerns both the syntagmatic level of causal chains (space and extension) and the paradigmatic level of associations and isotopes (history and memory). Built 
space is the activation and interpretation of a 'language' of structure and form in a specific context, which gives birth to a spatial narrative discourse. Style is a langue, a social contract. An individual expression of a specific architect is a parole, a speech producing meaning, namely: the speaker's use of the style [44]. We should, however, move from a semiotics of architectural language to a semiotics of architectural discourse. Every fictional architectural project takes its form and meaning within a context. The actor, the enunciator and the receiver of spatial meanings are the indispensable roles (performative modalities, if you like) for the implementation of narrative programmes and thematic values [45].

\subsection{Architecture, Semiosphere and Narratology}

We should study and think of the semiotics of space in the broader context of a 'semiotics of culture' (Juri Lotman) or a social semiotics (Bakhtin), insofar as it is system of signs that aims at the production of cultural meaning that is part of a code of social hierarchies and distinctions of collective values [46]. Architectural signs are expressive of conflicts between worldviews and they have strong symbolic connotations. To become a meaningful system, architecture needs the passage of time. Uses and functions, appropriations and changes specify the various messages that a place communicates. Through time, architecture is transformed from a language (system) to a narrative (oration, announcement). From a structural building code, it becomes a discourse that is dependent on time, traces, vestiges, events, customs, habits and forms of life. The meaning of a lived, discontinuous, semeiotic time is measured within architectural places.

I argue that the complexity of architectural signs implies an interdisciplinary methodological stance, which will broaden semiotics beyond the model of natural languages and the individual sign. Juri Lotman's concept of the 'semiosphere' may be very helpful in this case. He writes [47]: "in reality, clear and functionally mono-semantic systems do not exist in isolation... They function only by being immersed in a specific semiotic continuum, which is filled with multi-variant semiotic models situated at a range of hierarchical levels". He calls this continuum, a 'semiosphere'. The semiotic 'space of the semiosphere' is a unified organism with a structural heterogeneity, which acts as a prerequisite of every specific signatory act and which has a diachronic depth, a memory. It is a 'cultural space' that functions as a filter for semiotisation [48]. Given architecture's significance for the articulation of the world of culture as a whole, I claim that architectural space and the city play a major role in the construction and the production of a given semiosphere. Conversely, we cannot interpret architecture as a semiotic system without also considering the general environment, the cultural atmosphere, the whole semiosphere into which it belongs. Lotman's [49] concept of the semiosphere also has the advantage of offering a central role to the 'text': "there is a distinct parallelism between individual consciousness, the text and culture as a whole".

Following this interdisciplinary attitude, I propose a preliminary intersection between semiotics, literary theory and modal narratology. I suggest that we should move from formal semiotics to a modal narratology and, then, to a pragmatic theory of architectural communication, and a poetics of architectural conception, if we are to re-think architectural space as a narrative within a specific historical and social context (cultural codes). After all, as Lotman [50] wrote: "Meaning without communication is not possible". This move would allow us to transcend a descriptive formalisation of architecture as a static, final, built object and introduce time and dynamics in architecture considered as a social process for the formation of cultural meaning. To decipher the social values that are inherent in spatial forms, we need not only a general theory of their interpretation but we also need a theory of their manner of telling, their narrative structure, their plot, and how this plot is anchored and activated into specific and determinate social chronotopes. A possible strategy that would allow for this intersection to take place could be a broad conception of the notion of 'text' that includes 'space' as a narrative process, as a discourse that follows a specific 'narrative grammar' [51] without, however, adopting Greimas' static, descriptive and structuralist narratology of semiotic quadrangles (or squares). Architecture is not, only, or mainly, a language - it is a parole, a space-text which organises a narrative with a content made up of layers of meanings. Therefore, architectural semiotics should lay emphasis on the process of the conception, design, production and appropriation of spatial meaning as if this process was the writing of a social and "urban text",[52] a codification and an interpretation of a narrative in space. Leonid Tchertov [53] calls this process, which is based on various spatial codes and their articulations, a 'semiotopology of architectonic texts'. Just like a narrative (récit) organises actions in a plot, architecture organises spaces in a narrative and rhetoric of places. The design act can be considered as an ethical gesture in a social context [54]. After all, the city is a collective text (Raymond Ledrut).

In this paper, I will focus on a fragment of this immense project, examining some of the semiotic correlations and articulations between literature and architecture. My general working hypothesis is that architectural space can be conceived as a text creating a narrative. From this perspective, architectural design can be seen as a process that constructs a complex writing in space - a text that is related to a context: place. Therefore, based on Boudon's [55] three possible demarches for an architectural semiotics - namely: the formalist, the functionalist and the phenomenological - I choose the latter because it provides for a reading of the readings of urban space, instituting a 
redoubling of the signifiers. It is natural to look for new epistemological architectural models that are based on textuality and reading in a practice which creates narratives and texts all the time - that is, literature. My aim is to use these relations as a lever to revisit the timely problem of the various epistemological models that can be used for the projection and conception of architectural space, considered as an interdisciplinary series (sequence) of conceptual actions and decisions.

\subsection{Literature and Architecture}

The conceptual conjunctions and semiotic correlations between literature and architecture are very complex. Philippe Hamon, in his ground-breaking study titled Expositions, Literature and Architecture in Nineteenth-Century France unveils and investigates this complexity from the viewpoint of literary studies and textual poetics. Hamon focuses on the ways in which architecture becomes a privileged model grammar or incorporated meta-language for the construction of nineteenth-century French literary narratives. Hamon [56] views architecture as a shifter, a mathematical-metaphorical operator that enables the non-semiotic, visual domain of the 'real' to be translated into the semiotic, textual domain of the literary representation. Through architecture as a common denominator and background of experience, a 'mathematical operator' and a framing device, writers of fiction are enabled to produce a 'lexical space' that is imbued with intelligibility, structure and meaning.

However, it is unclear what the discipline of architecture or, more specifically, architectural design, can infer from these correlations between architecture and textuality. If Hamon's general research hypothesis that literature possesses a 'structural complicity' or a 'deep pre-established homology' with 'building' is correct, then what are its implications and consequences for the status and workings of architectural conception as a disciplined process for the organisation of space? I would like to begin the investigation of this question in the present paper.

I plan to adopt Hamon's hypothesis and lead it to further, specific directions of research, which are articulated around three different levels and plateaux of contemporary architectural problems: 1 . The problem of the nature and meaning of architectural and literary space as objects of conception; 2 . The problem of context and place in relation to memory and time; and 3. The problem of fiction and narrativity as vectors of the architect's creativity. My aim is to show how literature, and its various semiotic articulations and conceptual conjunctions with the situations of everyday life and their spatial setting entail a radical shift in the epistemological models of architectural conception. More specifically, I will briefly sketch a new methodology for the conception of architectural space that is based on these three levels of problems.

\section{Hamon's Hypothesis and the Problem of the Nature and Meaning of Architectural and Literary Space as Objects of Conception}

In his study, Hamon [57] formulates a basic working hypothesis: "the artifice of literature (an articulated semiotic ensemble that produces meaning) possesses a structural complicity or deep pre-established homology with that very thing whose existence in reality is already artificial: namely the building (an articulated semiotic ensemble that produces space)". What are the implications of this deep homology or affinity between the built domain of the visible and the written domain of the legible for the status of architecture as a discipline? Since August Schmarsow's lecture on The Essence of Architectural Creation, we have been familiar with the fact that the discipline of architecture creates space. The first questions that I would like to raise are - how does literature represent the space produced by architecture? And, can architects learn something from this process?

These questions have acquired urgency since another ground-breaking study: Joseph Frank's The Idea of Spatial Form. Trying to over-ride Lessing's assumption that literature deals with time-sequences, whereas the plastic arts are spatial in character, Frank [58] argues that modernist literature and contemporary literature are "striving to rival the spatial apprehension of the plastic arts in a moment of time". This predominance of spatial form can be attested in the works of Flaubert, Proust, Pound and Joyce. 'Space' is, therefore, an internal, relational logic of some modernist literary works that organise their form as a regulative idea [59]. The deep pre-established homology between literature and architecture is due to a common, spatial structure. If architecture offers an 'inhabitable story' (Aillaud) [60] in real space, then literature, through the spatialisation of its form, leads to a narrativisation of space.

It is, therefore, not uncommon to talk about literature's 'semantic spaces' [61], its 'narrative space' [62], its 'textual space' [63] and its 'oneiric' or 'paradoxical spaces' [64]. Consequently, I will reformulate my previous questions - If there is a 'literary' space, how does it represent 'architectural' space? And, how does it organise itself to produce meaning? Hamon [65] lists five (5) planes of "literary space", as an effect or a result of a production of meaning, which articulated around different hierarchical levels: (1) the topological, (2) the topographical, (3) the topical, (4) the typographical, and (5) the typological. I argue that architects could be particularly interested in the topographical level because it is the level of the signified collective actants, such as places, dwellings and architectural themes, and also of movements, rituals and proxemics [66]. From the topographical level of literary space, we can infer how literature represents the social space and the staging of everyday life that architecture 
produces.

I would, however, be reluctant to speak about 'literary spaces'. We should be epistemologically cautious. It is far better to talk about 'literary representations of space' or, following David Spurr [67], 'form of spatial representation'. Consequently, the fundamental question would be - what kind of space does literature represent (or present)? I argue the following three points: (1) Literature does not represent 'real space'. It is not a picture or a photographic image of the space of reality. It distorts, alters or transcends reality. We could even argue that literature shapes or invents reality, giving order to an amorphous mass of random facts (which Hamon calls a 'configuration'). Hamon [68] writes: "architecture is to space what narrative is to time: a semiotic means of configuration...which allows us to give shape to the amorphous and to impose discontinuity, plot and direction on the randomness of the real". (2) The topographical level of a literary spatial effect or spacing operation rewrites 'material space', suspending reality and distancing it from all of its details: it is a 'complicity of artificiality' which abstracts, transfers and transforms given facts or data into a semiosphere. (3) This set of transformations does not present geometrical space, which is measurable and quantifiable [69] but instead it unveils the intangible qualities [70] of the space of reality that often transcend immediate sensible data or sensual stimuli. As Hamon [71] observes, architecture leads to a "construction of differences that are qualitative and hence imperative". Literature represents these qualities through textuality and narrativity.

One specific example of this kind of spatial operations is Italo Calvino's Invisible Cities. Aside from its amazingly complex spatial structure, its strict architectural geography, and its internal mathematical organisation [72], this literary artefact deals specifically with the problem invoked by Hamon's hypothesis. Here, I quote Calvino [73]: "the city must never be confused with the words that describe it. And yet between the one and the other there is a connection". As Marco Polo describes the 55 cities of Kublai Khan's vast empire, a pressing enigma haunts the reader-Is he speaking of real or fictional and imaginary places? And, how does the narration of reality alter its meaning - through signs, images and the poetic use of language? What is the relationship between words and things? Calvino [74] writes: "Signs form a language, but not the one you think you know. I realised I had to free myself from the images which in the past had announced to me the things I sought".

Narrativity transforms real spaces into image-spaces, dreamscapes [75]. Sometimes, naming a reality is more important and more 'real' than reality itself: "the city that they speak of has much of what is needed to exist, whereas the city that exists on its site exists less" [76]. Therefore, Calvino [77] states that literature transforms real space into a "zodiac of the mind's phantasms". The literary vision "does not see things but images of things that mean other things" [78]. Literature unveils a latent, emotional space, articulated through signs: "Your gaze scans the streets as if they were written pages" [79]. This 'emotional space' is constituted by intangible qualities: memories and dreams. Let us call them the 'space of memory' [80] and the 'space of the imagination'. I argue that Hamon's topographical level of the literary representation of space is imbued with these types of spaces, forming what Calvino [81] calls a 'mental space'.

We could begin formulating an answer to our fundamental question. Literature represents, or rather reveals, a hidden spatial dimension-aspects of 'lived space', the space of 'experience'-, which is different from the real, material or geometrical space in so far as it is distorted and altered through various intellectual eyeglasses. Thus, if architecture assigns a structure to literature for the staging of the narrative plot, then literature in return offers a sense of the structure of lived, qualitative and experiential space, which I would like to name, after Husserl, the lebenswelt - that is, the life-world or the space-of-life.

\section{Husserl's Lebenswelt and the Problem of Context and Place in Relation to Memory and Time}

Let us, then, assume as a working hypothesis that literature, which is a specific type of discourse, gives us privileged access to the lebenswelt, namely to a 'space of experience' that is crystallised through narrative and the creative use of language. An obvious question naturally arises - what is the lebenswelt? The ambiguous concept of the lebenswelt, which can be translated as 'life-world' or 'world of life', was mainly expounded by Edmund Husserl in his magisterial but unfinished text The Crisis of European Sciences and Transcendental Phenomenology. Husserl worked on this major project from 1934 until 1937. His main aim was to expose and elaborate on the hidden precondition of scientific knowledge; a foundation which he believed remained unrecognised. Husserl [82] states: "Science is a human spiritual accomplishment which presupposes as its point of departure ... the intuitive surrounding world of life, pregiven as existing for all in common". The lebenswelt discloses the everyday world as a horizon, a framework and background of our lived experiences that is constituted through forms of meaning (Sinnesgestalten) [83]. This concept reminds us of the idea of a spatiotemporal 'environment' (Umgebung), a 'surrounding world', as elaborated by Husserl [84] in his lectures on "Thing and Space", in 1907.

This family resemblance led Edward Casey to advance certain arguments regarding the spatial dimension of Husserl's lebenswelt. In his important study, The Fate of Place, he shows how, in the early work of Husserl, the 
human living body (Leib) is entangled with a 'system of locations' (Ortssystem) that define a 'bodily space' (Leibesraum), a 'core world' (Kern-welt). He then proceeds [85] to almost identify the lebenswelt with this leibesraum. In other words, the lebenswelt would be a continuous system of possible locations of the living body [86]. I do not agree with Casey's interpretation. If we go back to Husserl's own primary texts, we will find that the lebenswelt does not necessarily coincide either with the scientific world of geometrical extension (Descartes) or with the materiality of a network of possible particular locations of bodies or things.

In Vienna, in 1935, Husserl delivered a revealing lecture that was titled "Philosophy and the Crisis of European Humanity". In it, he [87] concedes that:

[The] 'surrounding world' is a concept that has its place exclusively in the spiritual sphere. We live in our particular surrounding world, which is the locus of all our cares and endeavours - this refers to a fact that occurs purely within the spiritual realm. Our surrounding world is a spiritual structure in us and in our historical life.

A life-world is not, therefore, a system of objective locations but is instead a lived experience of this network [88]: a mental configuration or what Husserl [89] names a 'meaning-construct' (Sinngebilde). It is a "subjective-relative a priori" [90] which constitutes "a world-horizon as a horizon of possible thing-experience" [91]. Literature discloses such a world-horizon, revealing the lebenswelt, because, as Paul Ricoeur [92] writes, it denotes "the reservoir of meaning, the surplus of sense in living experience".

What would be the particular spatiality of concrete historical and cultural experiences that are so characteristic of the lebenswelt? If we carefully examine the various sections in the Crisis where Husserl [93] analyses the specific spatial structure of the lebenswelt, then we will find that it differentiates into particular 'regions', giving birth to subjective 'systems of correlations' mapping sectors of the world. These systems of correlations offer overlapping horizon-validities, which evaluate a given system of locations through the lens of a specific form or way of life [94]. The lebenswelt is a mental space that ascribes meaning to a place, capturing the qualitative experience of locality: it is a cultural world.

An example of this process can be found in a literary and autobiographical text that was written around the same period: Walter Benjamin's Berlin Childhood Around 1900. In his autobiography, Benjamin narrates his past through a collection of fragments, where childhood memories intermingle with the real localities of Berlin, accentuating certain spatial characteristics and recombining them into novel constellations of meaning. Memories and phantasms colour urban experience, relating certain spaces with feelings and emotional qualities. As Graham Livesey [95] wrote, a city is a collection of stories and every real city has a "...hidden fictional and dialectical counterpart", a dream order, a hidden topography that is made up by the imagination.

Benjamin [96] writes: "the imagination, once it has cast its veil over a region, likes to ruffle its edges with incomprehensible whims". The experience of Berlin through language, signs and street names unveils a child's perspective of the city: "How much was promised by the name 'Court Hunters' Lane', and how little it held!" [97]. Reality is constantly refracted through dreams, expectations and hopes, which are the lebenswelt of subjective world-horizons that is rooted in everyday practices and habits. Benjamin [98] notes:

Just as the lost word that was on the tip of our tongue would have triggered flights of eloquence worthy of Demosthenes, so what is forgotten seems to us laden with all the lived life it promises us. It may be that what makes the forgotten so weighty and so pregnant is nothing but the trace of misplaced habits in which we could no longer find ourselves.

Berlin Childhood Around 1900 is a literary, almost phenomenological, reconstruction of these lost habits, which is sewn around a qualitative nexus of lived spaces of experience. By organising these relational spaces into 'systems of correlations', with whom Benjamin was familiar from his archival practices, he reveals the Husserlian'life-world'. Literature, therefore, offers privileged access to the lebenswelt as a cultural world of values (Wertewelt) [99].

I will now proceed to the second point of my argument. Given that the lebenswelt is not a material form of location but the structure of experience that gives meaning to it, I claim that it bears a similarity to the concept of 'place' as used in human geography [100] —namely, a lived space, a meaningful location. Tim Cresswell [101] writes: "When humans invest meaning in a portion of space and then become attached to it in some way (naming is one such way) it becomes a place". In addition, Hamon [102] writes: "A place is never truly a place until it has become a named locality (lieu-dit)". Through naming and ascribing meaning to places and things, literary discourse reveals the lebenswelt that is hidden in spaces and localities. Mari Lending, examining Stendhal's autobiography, proves the place-making role of literature. In that sense, literature can contribute to what Josep Muntañola-Thornberg [103] calls 'topogenesis', namely, the "genetic and epistemological study of places" as cultural systems. Stendhal's textual corpus, which is based on his diagrammatic drawings, is a map of existential possibilities, an emotive geography capturing the physiognomy of a place [104]. Therefore, architecture could use literature to understand the 'genius loci', the spirit of a place. From a semiotic point of view, we could claim that the forms of a place are signs of present or even absent values: places are monuments of absences, as well as presences. Hamon [105] contends: "Architecture would therefore seem to have more to do with absence than 
with presence, and thus have more to do with writing". In that sense, the memory of a place, integral part of its genius loci, is related to narratives that activate absent values, creating meaning in the present. Pierre Pellegrino [106] has convincingly argued that narratives as a ritual, habit, memory and place are interconnected.

Christian Norberg-Schulz [107] writes:

Being qualitative totalities of a complex nature, places cannot be described by means of analytic, 'scientific' concepts. As a matter of principle, science 'abstracts' from the given to arrive at neutral, 'objective' knowledge. What is lost, however, is the everyday life-world, which ought to be the real concern ... of ... planners and architects.

Literature as a humanistic endeavour can, therefore, capture the elusive 'spirit of a place', which is related to the Husserlian lebenswelt. The spirit of the place is intimately connected with dwelling habits. Hamon [108] writes: "The act of dwelling involves living within 'distinctions' and inhabiting a system of values". I would like to call those distinctions and values the 'plot of a place', which are structures of the lebenswelt expressing ways of life. Adopting the terminology of Muntañola-Thornberg [109], the plot of a place is a 'lieu-récit'. What if the architect ought to read the lebenswelt of a place as a text? What would be the consequences for the methodology of architectural design and for the status, virtues and roles of the architect as a creative subject?

\section{Ricoeur's Refiguration and the Problem of Fiction and Narrativity as Vectors of the Architect's Creativity}

To offer some preliminary answers to those two questions, I will now turn to Paul Ricoeur's impressive essay, titled Architecture et Narrativité. In this essay, Ricoeur remoulds Hamon's hypothesis, trying to investigate the pre-established homology between architecture and narrative. He writes [110]:

I would like to put an analogy in place: a parallelism between, on the one hand, constructing, that is, building in space, and, on the other hand, narrating, recounting, emplotment in time... I will ask myself if one ought not to push this analogy much further, to the point of a genuine intertwining, an entanglement between the architectural configuring of space and the narrative configuring of time.

To arrive at their intersection, Ricoeur [111] uses the categories linked to threefold mimesis from his work Time and Narrative, transposing them to the architectural plane. The transposition makes use of the Heideggerian treatment of another famous triptych: building, dwelling and thinking [112].
The first logical moment of a literary creation is the prefiguration, where the narrative function is engaged in everyday life, in conversation, without detaching itself to produce literary form. Prefiguration is related to the act of dwelling. Then comes a second logical moment, the configuration, namely the stage on which time is organised according to a plot and the narrative acquires intelligibility. Ricoeur relates the second stage to the act of building. Finally, in the third step, that of refiguration, the literary creation arrives at the disposal of its reader. In the architectural realm, this third logical moment would entail a thoughtful dwelling [113]. Prefiguration is a way of living-together that refers to the lebenswelt. Configuration animates the problem of context and intertextuality in architectural creation. And refiguration opens up "the possibility of reading and re-reading our places of life from the point of view of our way of inhabiting" [114].

I would like to argue that Ricoeur's scheme could entail a radical shift in architectural pedagogy. Let us recall the dominant model of architectural creation, which is deeply rooted in the history of the discipline: first, there is process of conceiving an abstract idea, thinking in terms of a concept, which is then represented through sketches, models and plans. In a later stage, through the mediation of those graphic representations, construction and building begins, where materiality is shaped according to the initial idea. Finally, after the work of construction is over, dwelling begins. However, Ricoeur's scheme leads me to propose another possible alternative: why not merge the final stage (dwelling) into the first (thinking)? If we bring together refiguration and prefiguration into a single, holistic process of conception, then we gain something valuable: the anchoring of abstract thinking in the Husserlian lebenswelt.

Architectural ideas would, therefore, lose their formal, timeless, and, often, arbitrary nature. Pierre Pellegrino and Emmanuelle Jeanneret [115], reconstructing Rénier's epistemology, call this initial conception a 'conformation premiere', a static 'programmation'. This is juxtaposed to a 'second configuration', namely the lived space of the inhabitant, which is dynamic, an 'engrammation'. They write [116]: "From formation to configuration a play of relations develops between a text and its reader, within a context which leaves a place to interpretation". The second configuration, which is produced by the users, offers indexes of value, proxemic perspectives, from a real, lived environment (milieu) that relates actions to narrations and appropriates the abstract space of the architect's conception. These "narrativities in action" [117] relate to place and its spirit. This is where literature comes in. Literary representation, as we have seen, offers a privileged access to the lebenswelt of a place, namely to the lived space expressing ways of life. Literature could help architects to mediate between the abstract, mathematical-geometric space of conception (the 'conformation') and the concrete, experiential environment 
of the lived body. Ricoeur [118] names this the 'third space'. I argue here that the 'third space' can be accessed through literature and through narrative. Architectural creation then would be more like reading the con-text and 'plot' of the place and trying to adjust abstract ideas to concrete situations of life. Dwelling/thinking as reading should come before building. But exactly what does 'thoughtful dwelling' mean?

In Christian Norberg-Schulz's work titled The Concept of Dwelling, we read [119] that "human existence is qualified by the insoluble unity of life and place". Dwelling is related to the lebenswelt of a place, as a world of characteristic, meaningful things [120]. Therefore, dwelling is not only a material condition of shelter but is also a belonging to a place through phenomenological horizons of meaningful structures that affect the mind and the senses. In other words, dwelling creates ethos and character. Karsten Harries [121] writes: "Ethos...names the way human beings exist in the world: their way of dwelling". To illustrate how a plot or a "personhood of place" [122] can influence ethos through dwelling, I will turn to Edgar Allan Poe's story The Fall of the House of Usher.

In this story, Poe maps the influence of place on character through the concept of the 'atmosphere'. He writes [123]: "I had so worked upon my imagination as really to believe that around about the whole mansion and domain there hung an atmosphere peculiar to themselves and their immediate vicinity". The melancholic atmosphere of sorrow surrounding the House is mirrored in the mental idiosyncrasy of its proprietor, Roderick Usher, urging Poe [124] to admit of "the perfect keeping of the character of the premise with the accredited character of the people" who live there. Therefore, the place influences the formation of the ethos and mental conditions of its dwellers. Poe [125] observes "an effect which the physique of the grey walls and turrets ... had, at length, brought about upon the morale of [Usher's] existence". I argue that reading the plot of a place signifies a new task for the architect, which is to decipher the 'atmospheres' of dwelling as a decisive ethical factor in the design of space. The articulations between lived space, the character of the place (atmosphere) and human ethos can mediate between Husserl's 'system of correlations' and the inherent narrativity of built space. In relation to the final point, Hamon [126] writes: "Incarnating as it does prior narratives; the building also permits the subsequent reactivation of this narrativity and thus assumes its role as a shifter or redistributor of narrativity". Hamon actually proves my initial working hypothesis that architecture is a speech, a written text, an oration in space. He argues [127]: "The foundations or atmosphere of a building are first and foremost narrative, textual and literary, a building merely being a kind of 'frozen speech' (Rabelais)". As Pierre Pellegrino [128] writes: "The architectural project, project of a possible world, is basically a work of fiction".

\section{Conclusions}

Let us, therefore, recapitulate the arguments thus far to conclude. Hamon's hypothesis about a deep homology between literature and architecture leads to significant conceptual conjunctions between the two disciplines. These conjunctions entail a radical shift in the methodology of spatial design, which can be analysed in the following points:

1. Literature reveals hidden and intangible dimensions of space and, more specifically, a space of imagination and a space of memory.

2. Literary representations uncover the Husserlian lebenswelt, which is a lived space with qualitative and spiritual structures.

3. Literature can help architects to map the 'systems of correlations' that transform locations, through the lebenswelt, into meaningful places.

4. The architect, therefore, should read the lebenswelt of a place before building; thus merging abstract thinking with concrete situations of life, through literary representation.

5. This process of reading the plot of place as a critical dwelling would ultimately reveal the 'atmospheres' and the character of a place, and it would navigate architectural creation to contextualise a proposal appropriate to its ethos. As the world bursts into the literary text, place invades abstract space and colours it.

Moreover, architects can learn the following from literature and fiction in general:

1. How to investigate imaginatively possible worlds (Weiner) [129].

2. How to direct dwellers through dramatic sequences of embodied experiences (Pelletier) [130], just like a playwright. A spatial fiction is a vector of the creation of meaning on the part of the users, generating a narrative process which directs human actions.

3. How to reconstruct, re-activate, and re-write stories and discourses about places that influence the foundation of their atmospheres (Hamon) [131].

Finally, literature can help architects to realise that architecture is not a technical discipline that can be treated as an instrument or a commodity, as Dalibor Vesely [132] argues; rather, it is a complex discourse that is deeply rooted in the humanities [133]. Architects should produce stories of places and places that are stories [134]. Architecture is a 'concretization of narratives' [135]. The architect should become a narrator, a writer of space who will give meaning to human life. The proposed 
epistemological model of the architect's new role resembles the theory of argumentation that was developed by Jean-Blaise Grize: the presence of active subjects produces singular contents in a dialogical social context of an exchange of discourses. Pierre Pellegrino [136] rightly talks about logic of argumentation that is based on 'semiology of speech'. The schematisations within the architect's mind, his or her 'concepts', should be anchored in social representations that are organically related to pre-constructed cultural systems of values (Jacques Geminasca). Therefore, architectural conception is a discursive production of contextual social values [137] through spatial relations that create a plot. As Hayden White [138] writes: "A meaningful life is one that aspires to the coherency of a story with a plot". True architecture offers such a coherency.

\section{REFERENCES}

[1] For a very good synopsis of the history of semiotics in relation to architecture, see Pierre Pellegrino, Le Sens de l'Espace. Livre III. Les Grammaires et les Figures de l'Etendue, Anthropos, Paris, 2003, pp. 10-21

[2] Charles Jencks, "Semiology and Architecture", in Charles Jencks \& George Baird (eds.), Meaning in Architecture, Barrie \& Jenkins, 1969, pp. 11-12

[3] Charles Jencks, "Semiology and Architecture", op. cit., p. 13

[4] Geoffrey Broadbent, "A Plain Man's Guide to the Theory of Signs in Architecture", in Kate Nesbitt (ed.), Theorizing a New Agenda for Architecture. An Anthology of Architectural Theory, 1965-1995, Princeton Architectural Press, New York, 1996, pp. 124-125

[5] Geoffrey Broadbent, "A Plain Man's Guide to the Theory of Signs in Architecture”, op.cit., p. 133

[6] Charles Jencks, "Semiology and Architecture", op. cit., pp. $18-24$

[7] Charles Jencks, "Semiology and Architecture", op. cit., p. 17

[8] Gillo Dorfles, "Structuralism and Semiology in Architecture", in Charles Jencks \& George Baird (eds.), Meaning in Architecture, Barrie \& Jenkins, 1969, p. 39

[9] Alain Rénier, "Les Espaces Opérateurs de la Sémiosis Architecturale", in Actes Sémiotiques 111, 2008, available at: http://epublications.unilim.fr/revues/as/2939 (accessed 15 January 2017), pp. 3-5

[10] Gillo Dorfles, "Structuralism and Semiology in Architecture", op. cit., p. 40

[11] Gillo Dorfles, "Structuralism and Semiology in Architecture", op. cit., p. 48

[12] Geoffrey Broadbent, "Meaning into Architecture", in Charles Jencks \& George Baird (eds.), Meaning in Architecture, Barrie \& Jenkins, 1969, p. 56

[13] Philippe Hamon, Expositions, Literature and Architecture in
Nineteenth-Century France, Translated by Katia Sainson-Frank and Lisa Maguire, Introduction by Richard Sieburth, University of California Press, Berkeley, Los Angeles, Oxford, 1992, p. 43

[14] Geoffrey Broadbent, "Meaning into Architecture", op. cit., pp. 69,73

[15] Christian Norberg-Schulz, "Meaning in Architecture", in Charles Jencks \& George Baird (eds.), Meaning in Architecture, Barrie \& Jenkins, 1969, p. 223

[16] Christian Norberg-Schulz, "Meaning in Architecture", op.cit., pp. 215, 224-226

[17] Umberto Eco, "A Componential Analysis of the Architectural Sign /Column/", Semiotica V/2, 1972: 97. See also: Umberto Eco, La Structure Absente. Introduction à la Recherche Sémiotique, Traduit de l' Italien par Uccio Esposito-Torrigiani, Mercure de France, Paris, 1972, pp. 261-269

[18] Umberto Eco, "A Componential Analysis of the Architectural Sign /Column/", op. cit., p. 98

[19] Umberto Eco, La Structure Absente. Introduction à la Recherche Sémiotique, op.cit., pp. 271-277

[20] Umberto Eco, "A Componential Analysis of the Architectural Sign /Column/”, op. cit., p. 98

[21] Umberto Eco, "A Componential Analysis of the Architectural Sign /Column/”, op. cit., pp. 99-111

[22] Umberto Eco, "A Componential Analysis of the Architectural Sign /Column/”, op. cit., p. 113

[23] Umberto Eco, "A Componential Analysis of the Architectural Sign /Column/”, op. cit., p. 115

[24] Mario Gandelsonas, "Linguistics in Architecture", in K. Michael Hays (ed.), Architecture / Theory / since 1968, The MIT Press, Cambridge, MA., London, England, 2000, pp. $116-118$

[25] Umberto Eco, La Structure Absente. Introduction à la Recherche Sémiotique, op.cit., pp. 302-310

[26] Umberto Eco, La Structure Absente. Introduction à la Recherche Sémiotique, op.cit., p. 311. My translation.

[27] Mario Gandelsonas, "Linguistics in Architecture", op. cit., p. 119

[28] Albert Levy, "Architectural Conception, Semiotic Approach", in ELSA, Environment, Land, Society: Architectonics, Vol. 2: I-II, 2010, pp. 113-132, esp. pp. $121-123,128-129$

[29] Kristina Juodinyte-Kuznetsova, "Architectural Space and Greimassian Semiotics", in Societal Studies 3(4), 2011: 1270

[30] Roland Barthes, "Semiology and Urbanism", in Joan Ockman (ed.), Architecture Culture 1943-1968, A Documentary Anthology, Rizzoli International Publications, Inc., New York, 1993, p. 417

[31] Roland Barthes, "Semiology and Urbanism", op. cit., pp. 415,418

[32] A.J. Greimas, "Pour Une Sémiotique Topologique", in Jean 
Zeitoun (ed.), Sémiotique de l'Espace, Denoël/Gonthier, Paris, 1979, p. 14 [My translation]

[33] A.J. Greimas, "Pour Une Sémiotique Topologique”, op. cit., pp. 15,40

[34] A.J. Greimas, "Pour Une Sémiotique Topologique", op. cit., pp. 18-20, 27-28, 34, 37, 42

[35] Roland Barthes, "Semiology and Urbanism", op. cit. p. 415

[36] A.J. Greimas, "Pour Une Sémiotique Topologique”, op. cit., pp. 39, 24-25, 31 [My translation]

[37] A. Renier, "Nature et Lecture de l'Espace Architectural. Essai de Définition de l'Espace Architectural et Étude de son Système de Lecture", in Jean Zeitoun (ed.), Sémiotique de l' Espace, Denoël/Gonthier, Paris, 1979, pp. 45-59, especially p. 54

[38] G. Broadbent, "An Interview on Meaning in Architecture", M.E.T.U. Journal of the Faculty of Architecture, Volume 6, Number 1, Spring 1980, p. 13

[39] Alain Rénier, "Les Espaces Opérateurs de la Sémiosis Architecturale", op. cit., pp. 5-9

[40] Pierre Boudon, "Introduction", in Communications 27, 1977: pp. 2, 5, 7, 9

[41] Pierre Boudon, "Introduction”, op.cit., p. 2

[42] A.J. Greimas, "Pour Une Sémiotique Topologique", op. cit., p. 36

[43] Kristina Juodinyte-Kuznetsova, "Architectural Space and Greimassian Semiotics", in Societal Studies 3(4), 2011: $1270-1271$

[44] Gillo Dorfles, "Structuralism and Semiology in Architecture", op. cit., p. 40 [Broadbent] and Geoffrey Broadbent, "Meaning into Architecture", in Charles Jencks \& George Baird (eds.), Meaning in Architecture, Barrie \& Jenkins, 1969, pp. 51-54

[45] Kristina Juodinyte-Kuznetsova, "Architectural Space and Greimassian Semiotics”, op.cit., pp. 1271, 127, 1275-1276, 1278

[46] A.J. Greimas, "Pour Une Sémiotique Topologique", op. cit., p. 40

[47] Juri Lotman, "On the Semiosphere", in Sign Systems Studies 33.1: 2005, p. 206

[48] Juri Lotman, “On the Semiosphere”, op. cit., pp. 207-208, 210-211, 214, 219

[49] Juri Lotman, “On the Semiosphere”, op. cit., p. 216

[50] Juri Lotman, “On the Semiosphere”, op. cit., p. 218

[51] Pierre Pellegrino, "Space, Time, Semiotics", in ELSA, Environment, Land, Society: Architectonics, Vol. 2: I-II, 2010, p.10

[52] Roland Barthes, "Semiology and Urbanism”, op. cit., p. 415

[53] Leonid Tchertov, "On Visual-Spatial Codes in Architecture", in ELSA, Environment, Land, Society: Architectonics, Vol. 2: I-II, 2010, pp. 73-77, 84
[54] Gillo Dorfles, "Structuralism and Semiology in Architecture", op. cit., p. 44 [Baird]

[55] Pierre Boudon, "Introduction”, op.cit., pp. 9-10

[56] Philippe Hamon, Expositions, Literature and Architecture in Nineteenth-Century France, Translated by Katia Sainson-Frank and Lisa Maguire, Introduction by Richard Sieburth, University of California Press, Berkeley, Los Angeles, Oxford, 1992, pp. xi-xii, 12-13, 19-22, 24-25.

[57] Philippe Hamon, Expositions, Literature and Architecture in Nineteenth-Century France, op. cit., p. 6.

[58] Joseph Frank, The Idea of Spatial Form, Rutgers University Press, New Brunswick and London, 1991, p. 61.

[59] Joseph Frank, The Idea of Spatial Form, op. cit., pp. 9-10, $14-27$.

[60] Philippe Hamon, Expositions, op. cit., p. 29.

[61] Op. cit., p. 45.

[62] Louise Pelletier, "The Space of Fiction. On the Cultural Relevance of Architecture", in Paul Emmons, John Hendrix and Jane Lomholt (eds.), The Cultural Role of Architecture: Contemporary and Historical Perspectives, Routledge, London and New York, 2012, p. 64.

[63] David Spurr, "The Study of Space in Literature: Some Paradigms", in David Spurr and Cornelia Tschichold (eds.), The Space of English, Gunter NarrVerlag, Tübingen, 2005, p. 29.

[64] Alain Robbe Grillet and Alberto Pérez-Gómez, "Paradoxical Spaces in Literature, Film and Architecture: A Dialogue with Alain Robbe-Grillet", in Alberto Pérez-Gómez and Stephen Parcell (eds.), Chora Volume Two, Intervals in the Philosophy of Architecture, McGill-Queen's University Press, Montreal \& Kingston, London, Buffalo, 1996, pp. 250, 258.

[65] Philippe Hamon, Expositions, op. cit., pp. 34-35.

[66] Op. cit., p. 34

[67] David Spurr, "The Study of Space in Literature: Some Paradigms", op. cit., p. 16.

[68] Philippe Hamon, Expositions, op. cit., p. 35

[69] David Spurr, "The Study of Space in Literature: Some Paradigms", op. cit., p. 15.

[70] Frank Weiner, "Five Critical Horizons for Architectural Educators in an Age of Distraction", in EAAE News Sheet, 72 , June 2005 , p. 24 . According to Weiner, literature is "the canonization of an 'intangible' tradition", op. cit.

[71] Philippe Hamon, Expositions, op. cit., p. 32

[72] For an extensive treatment of these subjects see John Peponis, Choreographies of Space, The Architectural Schematization of Meaning, Alexandreia Publications, Athens, 1997 (In Greek), pp. 37-53.

[73] Italo Calvino, Invisible Cities, Translated from the Italian by William Weaver, A Harvest Book, Harcourt, Inc., Orlando, London, 1974, p. 61.

[74] Italo Calvino, Invisible Cities, op. cit., p. 48. 
[75] Op. cit., p. 44.

[76] Op. cit., p. 67.

[77] Op. cit., p. 22.

[78] Op. cit., p. 13.

[79] Op. cit., p. 14.

[80] Op. cit., p. 19.

[81] Op. cit., p. 103.

[82] Edmund Husserl, The Crisis of European Sciences and Transcendental Phenomenology, An Introduction to Phenomenological Philosophy, Translated, with an introduction, by David Carr, Northwestern University Press, Evanston, 1970, p. 121. See also pp. 111-112.

[83] Edmund Husserl, "The Way into Phenomenological Transcendental Philosophy by Inquiring back from the Pregiven Life-World", in Dermot Moran Timothy and Mooney (eds.), The Phenomenology Reader, Routledge, London and New York, 2002, pp. 152-157, 163-165, esp. 157.

[84] Edmund Husserl, Thing and Space, Lectures of 1907, Translated by Richard Rojcewicz, Kluwer Academic Publishers, Dordrecht, Boston, London, 1997, pp. 1-4. See also David Woodruff Smith, Husserl, Routledge, London and New York, 2007, p. 344.

[85] Edward Casey, The Fate of Place. A Philosophical History, University of California Press Berkeley, CA, 1997, pp. 216-220.

[86] Edward Casey, The Fate of Place. A Philosophical History, op. cit., pp. 224-228, 437, n. 141.

[87] Edmund Husserl, "Philosophy and the Crisis of European Humanity", in Edmund Husserl, The Crisis of European Sciences and Transcendental Phenomenology, An Introduction to Phenomenological Philosophy, Translated, with an introduction, by David Carr (ed.), Northwestern University Press, Evanston, 1970, p. 272.

[88] Jean-François Lyotard, Phenomenology, Translated by Brian Beakley, Foreword by Gayle L. Ormiston, State University of New York Press, Albany, 1991, pp. 61-64.

[89] Edmund Husserl, The Crisis of European Sciences and Transcendental Phenomenology, An Introduction to Phenomenological Philosophy, op. cit., p. 113.

[90] Edmund Husserl, The Crisis of European Sciences and Transcendental Phenomenology, op. cit., p. 140.

[91] Op. cit., p. 138.

[92] Paul Ricoeur, "Phenomenology and Hermeneutics", in Dermot Moran and Timothy Mooney (eds.), The Phenomenology Reader, Routledge, London and New York, 2002, pp. 592-593.

[93] Edmund Husserl, The Crisis of European Sciences and Transcendental Phenomenology, op. cit., pp. 143-147, $161-167$.

[94] Eva-Maria Engelen, "Husserl, History, and Consciousness", in David Hyder and Hans-Jörg Rheinberger (eds.), Science and the Life-World, Essays on Husserl's 'Crisis of European
Sciences', Stanford University Press, Stanford, CA, 2010, pp. 136-149, esp. p. 143.

[95] Graham Livesey, "Fictional Cities", in Alberto Pérez-Gómez and Stephen Parcell (eds.), Chora Volume One, Intervals in the Philosophy of Architecture, McGill-Queen's University Press, Montreal \& Kingston, 1994, pp. 110, 112-113

[96] Walter Benjamin, "Berlin Childhood Around 1900", in Howard Eiland and Michael W. Jennings (eds.), Walter Benjamin, Selected Writings, Volume 3, 1935-1938, Translated by Edmund Jephcott, Howard Eiland et al., The Belknap Press of Harvard University Press, Cambridge, MA, and London, 2002, pp. 369-371.

[97] Walter Benjamin, "Berlin Childhood Around 1900", op. cit., p. 352 .

[98] Op. cit., p. 395.

[99] David Woodruff Smith, Husserl, op. cit., pp. 383-387 and David Carr, "Husserl's Problematic Concept of the Life-World", in Frederick A. Elliston and Peter McCormick (eds.), Husserl, Expositions and Appraisals, University of Notre Dame Press, Notre Dame, IN, 1977, pp. 208-211.

[100] Tim Cresswell, Place, A Short Introduction, Blackwell Publishing, Malden, MA, 2004, pp. 11, 19-34.

[101] Tim Cresswell, Place, A Short Introduction, op. cit., p. 10.

[102] Philippe Hamon, Expositions, Literature and Architecture in Nineteenth-Century France, op. cit., p. 45.

[103] Josep Muntañola Thornberg, "Remarques Epistemologiques sur la Sémiotique des Lieux", in Communications 27, 1977: pp. 13-14, 21

[104] Mari Lending, "Writing a Life from the Inside of a Drawing: Stendhal's Vie de Henry Brulard", in Alberto Pérez-Gómez and Stephen Parcell (eds.), Chora Volume Six, Intervals in the Philosophy of Architecture, McGill-Queen's University Press, Montreal \& Kingston, London, Ithaca, 2011, pp. 94-103.

[105] Philippe Hamon, Expositions, op. cit., p. 49

[106] Pierre Pellegrino, "Space, Time, Semiotics", in ELSA, Environment, Land, Society: Architectonics, Vol. 2: I-II, 2010, p. 16

[107] Christian Norberg-Schulz, Genius Loci, Towards a Phenomenology of Architecture, Rizzoli International Publications, Inc., New York, 1980, p. 8.

[108] Philippe Hamon, Expositions, op. cit., p. 5

[109] Josep Muntañola Thornberg, La Topogenèse. Fondement d'une Architecture Vivante, Anthropos, Paris, 1996, p. 15

[110] Paul Ricoeur, "Architecture and Narrativity", Ricoeur Studies, Vol. 7, No. 2 (2016): p. 31. See also: Paul Ricoeur, "Architecture et Narrativité", available at http://www.fondsricoeur.fr/uploads/medias/articles_pr/archi tectureetnarrativite2.PDF [20 November 2014] and Paul Ricoeur, "Architecture and Narrative", in Identity and Difference: Integration and Plurality in Today's Forms, Cultures between the Ephemeral and the Lasting, Catalogue of the Triennale di Milano, XIX Esposizione Internazionale, 
Translated by H. Evans, Milan, Electa, 1996, pp. 64-72.

[111] Paul Ricoeur, Memory, History, Forgetting, Translated by Kathleen Blamey and David Pellauer, The University of Chicago Press, Chicago and London, 2004, p. 527, n. 2.

[112] Martin Heidegger, "Building, Dwelling, Thinking", in Neil Leach (ed.), Rethinking Architecture, A Reader in Cultural Theory, Routledge, London and New York, 1997, pp. $100-109$.

[113] Paul Ricoeur, "Architecture et Narrativity", op. cit., pp. 33-39.

[114] Op. cit., p. 39.

[115] Pierre Pellegrino, Emmanuelle P. Jeanneret, "Configuration, Figure", in Actes Sémiotiques 111, 2008, available at: http://epublications.unilim.fr/revues/as/2966 (accessed: 15 January 2017), pp. 1-2

[116] Pierre Pellegrino, Emmanuelle P. Jeanneret, "Configuration, Figure", op. cit., p. 1. My translation.

[117] Pierre Pellegrino, Emmanuelle P. Jeanneret, "Configuration, Figure", op. cit., pp. 3-4

[118] Paul Ricoeur, Memory, History, Forgetting, op. cit., pp. $148-150$.

[119] Christian Norberg-Schulz, The Concept of Dwelling, On the Way to Figurative Architecture, Rizzoli International Publications, Inc., New York, 1985, p. 13.

[120] Christian Norberg-Schulz, The Concept of Dwelling, On the Way to Figurative Architecture, op. cit., p. 16.

[121] Karsten Harries, The Ethical Function of Architecture, MIT Press, Cambridge, MA, 1997, p. 4.

[122] Gregory Caicco (ed.), Architecture, Ethics, and the Personhood of Place, University Press of New England, Hanover and London, 2007, pp. 1-18.

[123] Edgar Allan Poe, "The Fall of the House of Usher", in Nina Baym et al. (ed.), The Norton Anthology of American
Literature, Fourth Edition, Volume I, W.W. Norton \&

Company, Inc., New York and London, 1994, p. 1464.

[124] Op. cit., p. 1464.

[125] Op. cit., p. 1466. Poe's emphasis.

[126] Philippe Hamon, Expositions, op. cit., p. 31

[127] Philippe Hamon, Expositions, op. cit., pp. 46-47

[128] Pierre Pellegrino, Emmanuelle P. Jeanneret, "Configuration, Figure", op. cit., p. 6. My translation.

[129] Frank Weiner, "Five Critical Horizons for Architectural Educators in an Age of Distraction", op. cit., p. 25.

[130] Louise Pelletier, "The Space of Fiction. On the Cultural Relevance of Architecture", op. cit., pp. 62-66.

[131] Philippe Hamon, Expositions, op. cit., pp. 29, 46-47.

[132] Dalibor Vesely, Architecture in the Age of Divided Representation. The Question of Creativity in the Shadow of Production, MIT Press, Cambridge, MA, 2004, p. 3.

[133] Dalibor Vesely, "Architecture as a Humanistic Discipline", in Soumyen Bandyopadhyay, Jane Lomholt, Nicholas Temple and Renée Tobe (eds.), The Humanities in Architectural Design, A Contemporary and Historical Perspective, Routledge, London and New York, 2010, pp. 189-200.

[134] Philippe Hamon, Expositions, op. cit., p. 29

[135] Philippe Hamon, Expositions, op. cit., p. 31

[136] Pierre Pellegrino, Le Sens de l'Espace. Livre III. Les Grammaires et les Figures de l'Etendue, op. cit., pp. 14-20

[137] Pierre Pellegrino, Le Sens de l'Espace. Livre III. Les Grammaires et les Figures de l'Etendue, op. cit., pp. 103-105

[138] Hayden White, The Content of the Form. Narrative Discourse and Historical Representation, The Johns Hopkins University Press, Baltimore and London, 1987, p. 173 